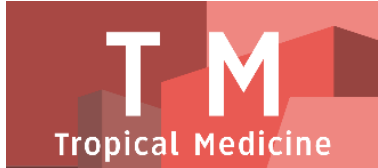

PAPER - OPEN ACCESS

\title{
Pembuatan Dan Karaterisasi Nanopartikel Ekstrak Etanol Daun Ekor Naga (Rhaphidophora pinnata (L.f.) Schott) Menggunakan Metode Gelasi Ionik
}
Author
: Sumaiyah
DOI
: 10.32734/tm.v1i3.257
Electronic ISSN
: 2623-0542
Print ISSN
: 2623-0550

Volume 1 Issue 3 - 2018 TALENTA Conference Series: Tropical Medicine (TM)

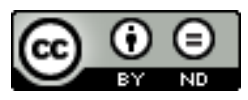

This work is licensed under a Creative Commons Attribution-NoDerivatives 4.0 International License.

Published under licence by TALENTA Publisher, Universitas Sumatera Utara
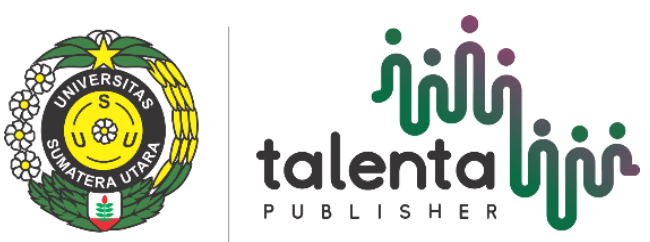


\title{
Pembuatan Dan Karaterisasi Nanopartikel Ekstrak Etanol Daun Ekor Naga (Rhaphidophora pinnata (L.f.) Schott) Menggunakan Metode Gelasi Ionik
}

\author{
Dian Ayumi ${ }^{\mathrm{a}}$, Sumaiyah ${ }^{\mathrm{b} *}$, Masfria $^{\mathrm{b}}$ \\ ${ }^{a b}$ Departemen Teknologi FormulasiFakultas Farmasi, Universitas Sumatera Utara, Medan 20155 \\ ${ }^{c}$ Departemen Kimia FarmasiFakultas Farmasi, Universitas Sumatera Utara, Medan 20155 \\ sumaiyah7777@gmail.com
}

\begin{abstract}
Abstrak
Pengobatan tradisional masih diminati. Salah satu tumbuhannya adalah daun ekor naga (Rhaphidophora pinnata (L.f.) Schott) yang digunakan sebagai obat antikanker dan antibakteri. Penggunaan nanoteknologi dalam sistem penghantaran obat terus diteliti dan dikembangkan. Penelitian ini bertujuan untuk membuat dan mengetahui sifat-sifat nanopartikel ekstrak etanol daun ekor naga (Rhaphidophora pinnata (L.f.) Schott) menggunakan metode gelasi ionik. Ekstrak daun ekor naga dibuat dengan metode maserasi menggunakan pelarut etanol 96\%. Nanopartikel dibuat dengan metode gelasi ionik, yaitu menggunakan larutan natrium tripolipospat 0,1\% dan kitosan 0,2\%, Nanopartikel kemudian dikarakterisasi menggunakan Particle Size Analyzer untuk mengetahui distribusi ukuran partikel dan Scanning Electron Microscopy untuk mengetahui bentuk permukaan partikel. Nanopartikel yang dihasilkan berupa serbuk berwarna coklat muda dengan distribusi ukuran partikel 234,49-1479,50 nm pada perbandingan kitosan 0,2\% dan natrium tripolipospat 0,1\% (5:1). Bentuk permukaan nanopartikel ekstrak etanol daun ekor naga yaitu tidak rata dan membentuk agregat longgar. Ekstrak etanol daun ekor naga dapat dibuat menjadi nanopartikel dengan kitosan $0,2 \%$ dan natrium tripolipospat $0,1 \%$ menggunakan metode gelasi ionik.
\end{abstract}

Kata kunci: Ekstrak, daun ekor naga, nanopartikel, karakteristik

\begin{abstract}
Traditional medicine is still in demand. One of the plants is Rhaphidophora pinnata (L.f.) Schott leaves which is an anticancer and anti-bacterial drug. The use of nanotechnology in drug delivery systems continues to be researched and developed. This study aimed to prepare and to know the characteristics of nanoparticle ethanol extract of Rhaphidophora pinnata leaves using ionic gelation method. Rhaphidophora pinnata leaves extract was made by maceration method using $96 \%$ ethanol solvent. The nanoparticles were prepared by ionic gelation method, using $0.1 \%$ sodium tripolyphosphate and $0.2 \%$ chitosan solution. The nanoparticles were then characterized using Particle Size Analyzer to know distribution of particle size and Scanning Electron Microscopy to know the surface shape of the nanoparticles. The resulting nanoparticles were light brown powder with particle size distribution $234.49-1479.50 \mathrm{~nm}$ in the ratio of chitosan $0.2 \%$ and sodium tripolipospate $0.1 \%(5: 1)$. The surface shape of nanoparticles of ethanol extract of Rhaphidophora pinnata leaves was uneven and formed loose aggregate. Ethanol extract of Rhaphidophora pinnata leaves can be made into nanoparticles with $0.2 \%$ chitosan and $0.1 \%$ sodium tripolipospate using ionic gelation method.
\end{abstract}

Keywords:Extracts, Rhaphidophora pinnata leaves, nanoparticles, characteristic 


\section{Pendahuluan}

Nanopartikel merupakan partikel dengan dimensi 1-1000 nm. Nanopartikel yang digunakan sebagai pembawa mengandung bahan yang senyawa aktifnya telah terlarut dan terenkapsulasi [1]. Prinsip pembentukan nanopartikel pada metode gelasi ionik adalah terjadinya interaksi ionik antara gugus amino pada kitosan yang bermuatan positif dengan polianion yang bermuatan negatif. Proses taut silang terjadi secara fisika. Pada proses ini penggunaan pelarut organik dapat dihindari dan kemungkinan rusaknya bahan aktif dapat dicegah [2].

\section{Bahan dan Metode}

Pengambilan sampel dilakukan secara purposive. Sampel yang digunakan dalam penelitian ini adalah daun ekor naga (Rhaphidophora pinnata (L.f.) Schott) yang diperoleh dari Kelurahan Glugur Darat 1, Kecamatan Medan Timur, Kota Medan, Provinsi Sumatera Utara

\subsection{Alat}

Alat yang digunakan yaitu blender, penguap vakum putar (rotary evaporator), magnetic stirrer, satu set alat homogenizer (WiseTis), satu set alat sentrifuse (K sentrifuse PLC series), freezer dan air cooler, satu set alat pengering, lumpang dan alu, Particle Size Analyzer (PSA) (NanoQ), dan Scanning Electron Microscopy (SEM) (TM 3000).

\subsection{Bahan}

Bahan yang digunakan yaitu daun ekor naga. Bahan kimia untuk ekstraksi yaitu etanol 96\%. Bahan kimia untuk sintesis nanopartikel yaitu kitosan, NaTPP (Natrium Tripolipospat), asam asetat 2\% dan akuades.

\subsection{Pembuatan Ekstrak Etanol Daun Ekor Naga (EEDEN)}

75 bagian etanol 96\% ditambahkan ke serbuk daun ekor naga, ditutup dan biarkan selama 5 hari terlindung dari cahaya sambil sekali-sekali diaduk dan kemudian dipisahkan dengan cara penyarian menggunakan kertas saring. 25 bagian etanol 96\% kemudian ditambahkan ke ampas dan biarkan selama 2 hari, kemudian pisahkan kembali. Seluruh maserat yang diperoleh digabungkan dan dipekatkan dengan alat penguap vakum putar pada suhu $50{ }^{\circ} \mathrm{C}$ sampai diperoleh ekstrak etanol daun ekor naga (EEDEN) yang cukup kental [3].

\subsection{Pembuatan Larutan Pereaksi}

Larutan Kitosan 0,2\%; 0,5\%

$0,2 \mathrm{~g} ; 0,5 \mathrm{~g}$ kitosan dilarutkan dalam $100 \mathrm{ml}$ asam asetat $2 \%$.

Larutan NaTPP 0,1\%

$0,1 \mathrm{~g}$ NaTPP dilarutkan dalam $100 \mathrm{ml}$ akuades.

\subsection{Pembuatan Nanopartikel Ekstrak Etanol Daun Ekor Naga}

Formula yang digunakan dalam pembuatan nanopartikel ekstrak etanol daun ekor naga tertera pada Tabel 1. 


\begin{tabular}{|c|c|c|}
\hline \multirow{2}{*}{$\begin{array}{c}\text { Formula } \\
\text { F1 }\end{array}$} & \multicolumn{2}{|l|}{ Komposisi } \\
\hline & EEDEN & $2 \mathrm{~g}$ \\
\hline & Etanol:Air (70:30) & $50 \mathrm{ml}$ \\
\hline & Kitosan $0,2 \%$ & $100 \mathrm{ml}$ \\
\hline & Akuades & $850 \mathrm{ml}$ \\
\hline & NaTPP $0,1 \%$ & $700 \mathrm{ml}$ \\
\hline \multirow[t]{5}{*}{$\mathrm{F} 2$} & EEDEN & $2 \mathrm{~g}$ \\
\hline & Etanol:Air (70:30) & $50 \mathrm{ml}$ \\
\hline & Kitosan $0,5 \%$ & $100 \mathrm{ml}$ \\
\hline & Akuades & $850 \mathrm{ml}$ \\
\hline & NaTPP $0,1 \%$ & $700 \mathrm{ml}$ \\
\hline \multirow[t]{5}{*}{$\mathrm{F} 3$} & EEDEN & $2 \mathrm{~g}$ \\
\hline & Etanol:Air (70:30) & $50 \mathrm{ml}$ \\
\hline & Kitosan 0,2\% & $100 \mathrm{ml}$ \\
\hline & Akuades & $350 \mathrm{ml}$ \\
\hline & NaTPP $0,1 \%$ & $100 \mathrm{ml}$ \\
\hline \multirow[t]{5}{*}{$\mathrm{F} 4$} & EEDEN & $2 \mathrm{~g}$ \\
\hline & Etanol:Air (70:30) & $50 \mathrm{ml}$ \\
\hline & Kitosan $0,5 \%$ & $100 \mathrm{ml}$ \\
\hline & Akuades & $350 \mathrm{ml}$ \\
\hline & NaTPP $0,1 \%$ & $100 \mathrm{ml}$ \\
\hline
\end{tabular}

Pembuatan nanopartikel ekstrak etanol daun ekor naga dilakukan dengan memvariasikan konsentrasi kitosan dan perlakuan. Dua gram ekstrak etanol daun ekor naga (EEDEN) dilarutkan dalam $50 \mathrm{ml}$ etanol:air (70:30) dan dicampurkan dengan $100 \mathrm{ml}$ larutan kitosan 0,2\% (F1 dan F3) atau 0,5\% (F2 dan F4) dserta diencerkan dengan akuades hingga $500 \mathrm{ml}$. Kemudian secara bertahap ditambahkan $100 \mathrm{ml}$ larutan NaTPP 0,1\% sambil disertai pengadukan pada 12.500 rpm selama 1 atau 2,5 jam (1 jam untuk F1 dan F2, 2,5 jam untuk F3 dan F4), kemudian disonikasi selama 1 jam (untuk F3 dan F4) atau tidak disonikasi (untuk F1 dan F2), selanjutnya dipisahkan dengan cara sentrifugasi. Endapan kemudian dibekukan dalam lemari pendingin pada suhu sekitar $-18^{\circ} \mathrm{C}$ selama 24 jam, dikeringkan dengan air cooler dan pemanasan pada suhu $40^{\circ} \mathrm{C}$. Serbuk kering yang diperoleh digerus dalam lumpang selama \pm 3 jam $[2,4,5]$.

\subsection{Karakterisasi Nanopartikel}

Karakterisasi nanopartikel menggunakan Particle Size Analyzer (PSA) untuk mengetahui distribusi ukuran partikel yang terbentuk dan Scanning Electron Microscopy (SEM) untuk mengetahui kondisi bentuk permukaan partikel dan diukur pada perbesaran 1500x

\section{Hasil Dan Pembahasan}

\subsection{Hasil Ekstraksi Daun Ekor Naga (Rhaphidopora pinnata (L.f.) Schott)}

Hasil ekstraksi dengan pelarut etanol 96\% diperoleh sebanyak 71 g. Berat simplisia daun ekor naga yang digunakan untuk ekstraksi adalah $1 \mathrm{~kg}$. Persen rendemennya adalah 7,1\%. 


\subsection{Nanopartikel Ekstrak Etanol Daun Ekor Naga}

Pembuatan nanopartikel ekstrak etanol daun ekor naga dilakukan dengan metode gelasi ionik, yakni dengan menggunakan NaTPP sebagai bahan pengikat silang dengan kitosan. Nanopartikel terbentuk merupakan hasil interaksi elektrostatik antara gugus poaitif amina dari kitosan dan gugus negatif dari polianion pada tripolifosfat [1]. Hasil ukuran partikel dapat dilihat pada Tabel 2.

Tabel 2. Ukuran partikel ekstrak etanol daun ekor naga setelah penambahan kitosan dan NaTPP

\begin{tabular}{|c|c|c|c|c|c|c|}
\hline Formula & Kitosan (\%) & $\mathrm{Na}$ TPP (\%) & $\begin{array}{l}\text { Rasio } \\
\text { Kitosan: } \mathrm{Na} \\
\text { TPP }\end{array}$ & Cara Preparasi & $\begin{array}{l}\text { Distribusi } \\
\text { Ukuran } \\
\text { Partikel }\end{array}$ & $\begin{array}{l}\text { Ukuran } \\
\text { Rata-rata } \\
\text { Partikel }\end{array}$ \\
\hline F1 & 0,2 & 0,1 & $10: 7$ & $\begin{array}{l}\text { Pengadukan } \\
\text { selama } 1 \text { jam, } \\
\text { penggerusan } \\
\text { selama } \pm 3 \text { jam }\end{array}$ & $5,1-394,2 \mu \mathrm{m}$ & $31,6 \mu \mathrm{m}$ \\
\hline $\mathrm{F} 2$ & 0,5 & 0,1 & $10: 7$ & $\begin{array}{l}\text { Pengadukan } \\
\text { selama } 1 \text { jam } \\
\text { penggerusan } \\
\text { selama } \pm 3 \text { jam }\end{array}$ & $\begin{array}{l}10,1-394,2 \\
\mu \mathrm{m}\end{array}$ & $45,8 \mu \mathrm{m}$ \\
\hline F3 & 0,2 & 0,1 & $5: 1$ & $\begin{array}{l}\text { Pengadukan } \\
\text { selama } 2,5 \text { jam, } \\
\text { sonikasi selama } 1 \\
\text { jam, }\end{array}$ & $\begin{array}{l}234,5-1479,5 \\
\mathrm{~nm}\end{array}$ & $659,5 \mathrm{~nm}$ \\
\hline $\mathrm{F} 4$ & 0,5 & 0,1 & $5: 1$ & $\begin{array}{l}\text { Pengadukan } \\
\text { selama } 2,5 \text { jam, } \\
\text { sonikasi selama } 1 \\
\text { jam, }\end{array}$ & $1,4-51,5 \mu \mathrm{m}$ & $11,8 \mu \mathrm{m}$ \\
\hline
\end{tabular}

Data pada Tabel 2 menunjukkan bahwa ukuran partikel dipengaruhi oleh konsentrasi, rasio volume kitosan dan NaTPP serta cara preparasi yang digunakan, dimana ukuran partikel bertambah dengan bertambahnya konsentrasi kitosan. Pada konsentrasi kitosan 0,2\% pembuatan nanopartikel relatif lebih mudah dilakukan dan terbentuknya partikel berukuran mikro tidak terlalu banyak sedangkan pada konsentrasi kitosan 0,5\% partikel mikro lebih mudah terbentuk, yang ditandai adanya kabut suspensi pada larutan sampel dengan cepat. Ukuran partikel meningkat dengan meningkatnya volume larutan kitosan dan NaTPP, Semakin kecil rasio volume yang digunakan maka memiliki rentang distribusi yang pendek sehingga tingkat keseragaman yang baik pula [2]. Ukuran partikel semakin kecil dengan pengadukan yang lama disertai sonikasi, hal ini dikarenakan fungsi ultrasonikasi yaitu sebagai alat untuk memecahkan molekul polimer menjadi berukuran kecil. Semakin lama waktu ultrasonikasi maka proses pemecahan molekul akan terus berjalan [5].

\subsection{Karakterisasi Nanopartikel}

Karakterisasi nanopartikel meliputi penentuan distribusi ukuran partikel dan analisis morfologi partikel. Karakterisasi menggunakan PSA menunjukkan hasil dalam skala nano dengan ratio konsentrasi kitosan 0,2\%:NaTPP $0,1 \%$ (5:1), ukuran nano yang terbentuk yaitu 234,49-977,50 $\mathrm{nm}$.

Karakterisasi menggunakan SEM menunjukkan bentuk permukaan nanopartikel ekstrak etanol daun ekor naga dengan bentuk agregat longgar dan permukaan yang tidak rata. Hasil SEM dapat dilihat pada Gambar 1. 


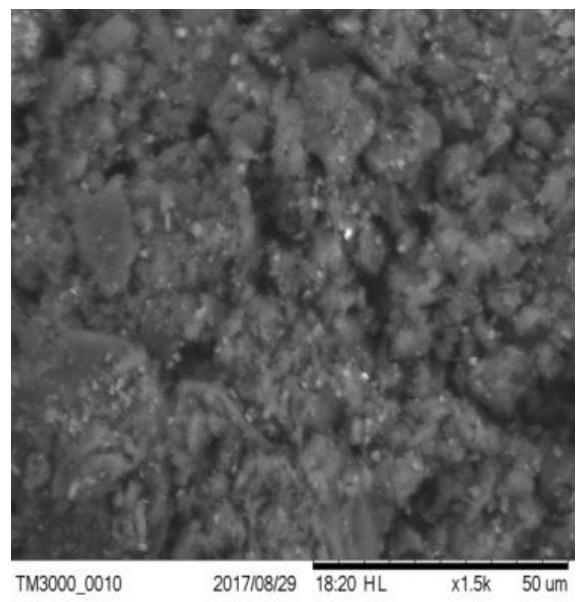

a

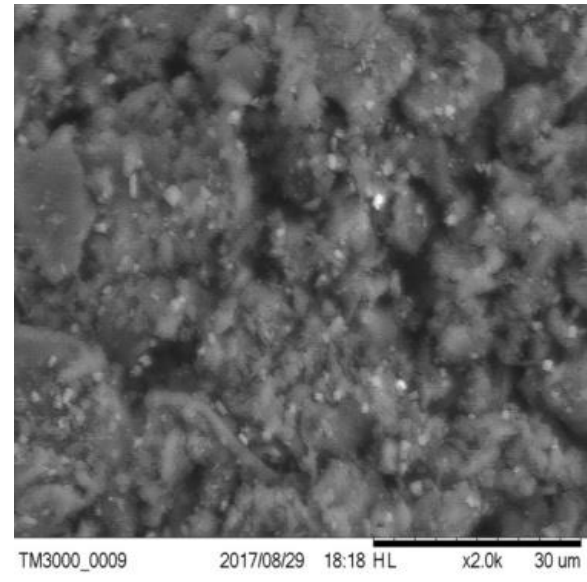

$\mathrm{b}$

Gambar 1. SEM Nanopartikel Ekstrak Etanol Daun Ekor Naga Perbesaran 1500x (a) danPerbesaran 2000x (b)

\section{Kesimpulan}

Berdasarkan hasil penelitian di atas, maka dapat disimpulkan bahwa ekstrak etanol daun ekor naga dapat dibuat menjadi nanopartikel dengan menggunakan metode gelasi ionik yaitu dengan cara mereaksikan campuran ekstrak etanol daun ekor naga $2 \mathrm{~g}$, larutan kitosan 0,2\%, akuades dan NaTPP 0,1\%. Pengadukan pada 12.500 rpm selama 1 jam, penggunaan konsentrasi kitosan 0,2\% menghasilkan ukuran partikel 5,1-394,2 $\mu \mathrm{m}$ dan konsentrasi kitosan 0,5\% menghasilkan ukuran partikel 10,1-394,2 $\mu \mathrm{m}$. Pengadukan pada $12.500 \mathrm{rpm}$ selama 2,5 jam dan sonikasi selama 1 jam, penggunaan konsentrasi kitosan 0,2\% menghasilkan ukuran partikel 234,5-1479,5 nm dan konsentrasi kitosan $0,5 \%$ menghasilkan ukuran partikel 1,4-51,5 $\mu \mathrm{m}$.

\section{Ucapan Terima Kasih}

Penulis mengucapkan terimakasih kepada Fakultas Farmasi USU yang telah menyediakan fasilitas dalam menyelesaikan penelitian ini.

\section{Daftar Pustaka}

[1] Kurniasari, D., dan Atun, S. (2017). Pembuatan Dan Karakterisasi Nanopartikel Ekstrak Etanol Temu Kunci(Boesenbergia pandurata) Pada Berbagai Variasi Komposisi Kitosan. Jurnal Sains Dasar. 6 (1): 31-35.

[2] Mardliyati, E., Muttaqien, S.E., dan Setyawati, D.R. (2012). Sintesis Nanopartikel Kitosan-Tripoly Phosphate Dengan Metode Gelasi Ionik:Pengaruh Konsentrasi Dan Rasio VolumeTerhadap Karakteristik Partikel.Prosiding Pertemuan Ilmiah Ilmu Pengetahuan dan Teknologi Bahan 2012. Halaman 90-93.

[3] Depkes RI. (1979). Farmakope Indonesia. Edisi III. Jakarta, Departemen Kesehatan Republik Indonesia. Halaman 33.

[4] Rismana, E., Kusumaningrum, S., Bunga, O., Nizar, dan Marhamah. (2014). Pengujian Aktivitas Antiacne Nanopartikel Kitosan - Ekstrak Kulit Buah Manggis (Garcinia mangostana). Media Litbangkes. 24 (1): 19-27.

[5] Sidqi, T. (2011). Pembuatan Dan Karakterisasi Nanopartikel Ekstrak Temulawak Dengan Metode Ultrasonik.Skripsi. Halaman 8-13. 